\title{
PENGARUH PENYARUNGAN BUAH DAN APLIKASI ASAM FOSFIT TERHADAP HAMA PENGGEREK DAN PENYAKIT BUSUK BUAH KAKAO
}

\author{
Muhammad Deri Bastian, Joko Prasetyo, Tri Maryono \& F.X. Susilo \\ Jurusan Agroteknologi, Fakultas Pertanian Universitas Lampung \\ J1. Prof. Dr. Soemantri Brodjonegoro no. 1 Bandar Lampung 35145 \\ Email : deri_bastian@rocketmail.com
}

\begin{abstract}
ABSTRAK
Hama penggerek buah dan penyakit busuk buah adalah masalah utama dalam budidaya kakao. Larva penggerek buah kakao setelah menetas langsung masuk dan berkembang di dalam buah. Sedangkan spora patogen mudah berkecambah bila kondisi lembab. Penyarungan buah kakao sejak masih muda dapat menjadi upaya pencegahan penggerek buah dan penyakit busuk buah yang baik. Namun penyarungan buah mengakibatkan kondisi buah menjadi lembab sehingga busuk buah kakao meningkat. Untuk menekan penyakit busuk buah kakao maka perlu dilakukan penyemprotan fungisida, sebelum buah disarungi. Salah satu bahan aktif fungisida yang diteliti efektif untuk menekan pertumbuhan Phytophthora adalah asam fosfit. Penelitian ini bertujuan mengetahui pengaruh penyarungan buah dan aplikasi asam fosfit terhadap hama penggerek dan penyakit busuk buah kakao. Penelitian ini dilakukan dengan menggunakan rancangan faktorial menggunakan dua faktor, yaitu penyarungan buah dan penyemprotan fungisida asam fosfit. Data hasil pengamatan dianalisis secara statistik deskriptif. Hasil penelitian menunjukkan penyarungan buah dapat melindungi buah dari hama penggerek buah, namun penyarungan buah menyebabkan buah yang terserang busuk buah menjadi meningkat. Aplikasi fungisida berbahan aktif asam fosfit terlihat dapat mengendalikan busuk buah kakao jika buah tidak disarungi plastik, namun aplikasi fungisida berbahan aktif asam fosfit menjadi lebih rendah keefektifannya jika buah disarungi.
\end{abstract}

Kata kunci : Asam fosfit, penggerek buah busuk buah kakao (Phytophthora palmivora), penyarungan buah.

\section{PENDAHULUAN}

Kakao (Theobroma cacao L.) merupakan salah satu komoditi ekspor nonmigas andalan Indonesia. Indonesia adalah negara pengekspor kakao terbesar ke 3 dunia setelah Pantai Gading dan Ghana. Produksi kakao Indonesia rata-rata 792.761 ton/ tahun dan total ekspor 655.429 ton atau senilai US\$ 950,6 juta. Sentra kakao di Indonesia tersebar di Sulawesi $(63,8 \%)$, Sumatera (16,3\%), Jawa (5,3\%), Nusa Tenggara Timur, Nusa Tenggara Barat dan Bali (4,0\%), Kalimantan (3,6\%), Maluku dan Papua (7,1\%) (Departemen Pertanian, 2013).

Di Indonesia kehilangan hasil akibat serangan hama penggerek buah kakao (PBK) mencapai 80\% (Wiryadiputra et al., 1994 dalam Misnawi dan Teguh, 2008). Pada tahun 2013 di beberapa daerah sentra tanaman kakao di Indonesia, biji yang rusak karena serangan penggerek buah kakao mencapai $82 \%$ (Balai Besar Pelatihan Pertanian, 2013a), sedangkan kehilangan hasil panen akibat penyakit busuk buah mencapai 41-53\% (Balai Besar Pelatihan Pertanian, 2013b). Di Lampung pada tahun 2009 dilaporkan jumlah produksi buah kakao di Kabupaten Pringsewu turun sampai 50\% akibat serangan hama penggerek buah kakao (Republika Online, 2009) dan kehilangan produksi akibat penyakit busuk buah kakao di Kalirejo, Lampung Tengah pada tahun 2013 dilaporkan turun hingga 90\%. Hampir tidak ada petani di Kalirejo yang panen (Radar Lampung, 2013).

Hama penggerek buah dan penyakit busuk buah kakao sangat sulit dikendalikan. Larva penggerek buah kakao setelah menetas dari telur langsung masuk dan berkembang didalam buah kakao. Sehingga larva tidak akan terjangkau dengan musuh alami atau insektisida karena selama hidupnya larva berada didalam buah kakao (Depparaba, 2002). Sedangkan spora patogen mudah berkecambah untuk menginfeksi buah kakao bila kondisi lembab dan penyebaran spora patogen dari sumber penyakit ke bagian tanaman yang masih sehat melalui percikan air (Balai Besar Pelatihan Pertanian, 2013b). Berbagai metode pengendalian telah dicoba, namun belum berhasil mengendalikan PBK dan penyakit busuk buah kakao, oleh karena itu perlu dicari alternatif 
pengendalian lain. Salah satu pengendalian yang efektif untuk mengendalikan hama penggerek buah kakao adalah dengan melakukan penyarungan buah dengan plastik (Mustafa, 2005), namun penyarungan buah mengakibatkan kondisi buah menjadi lembab sehingga busuk buah kakao meningkat. Untuk menekan pertumbuhan busuk buah kakao maka perlu dilakukan penyemprotan fungisida, sebelum buah disarungi. Salah satu bahan aktif fungisida yang diteliti efektif untuk menekan pertumbuhan Phytophthora adalah asam fosfit (Roesmiyanto et al., 2000).

Penelitian ini bertujuan mengetahui pengaruh penyarungan buah dengan plastik dan aplikasi asam fosfit terhadap hama penggerek dan penyakit busuk buah kakao.

\section{BAHAN DAN METODE}

Penelitian ini telah dilaksanakan dari bulan Desember 2013 sampai April 2014. Percobaan dilakukan di perkebunan kakao rakyat, Way Laga, Bandar Lampung. Rancangan percoban yang digunakan adalah rancangan faktorial yang terdiri dari faktor A yaitu penyarungan buah kakao \{(tanpa penyarungan buah (A0), penyarungan buah (A1) $\}$ dan faktor B yaitu penyemprotan fungisida asam fosfit tanpa penyemprotan fungisida asam fosfit (B0) dengan penyemprotan fungisida asam fosfit (B1)\}. Setiap perlakuan diulang sebanyak 5 kali, jumlah satuan percobaan adalah 20 satuan percobaan dan buah yang digunakan dalam setiap satuan percobaan sebanyak 10 buah.

Penentuan pohon sampel dilakukan dengan menggunakan rancangan acak sempurna. Seluruh pohon kakao di lahan penelitian yang berpotensi menjadi sampel penelitian (pohon yang memiliki 10 buah atau lebih) dihitung dan diberi nomor pada batang pohon. Setelah seluruh pohon yang berpotensi menjadi pohon sampel dihitung dan diberi nomor, dipilih 20 pohon yang akan dijadikan sampel menggunakan angka acak.

Setelah pohon sampel ditentukan, setiap pohon sampel dipilih 10 buah yang panjangnya berkisar 10-15 $\mathrm{cm}$ diberi label sesuai perlakuan yang diberikan. Aplikasi fungisida menggunakan alat semprot hand sprayer semi otomatis. Fungisida yang digunakan adalah fungisida sistemik berbahan aktif asam fosfit. Penyemprotan dilakukan pada perlakuan aplikasi fungisida $\left(\mathrm{A}_{0} \mathrm{~B}_{1}\right)$ dan kombinasi penyarungan buah kakao dengan aplikasi fungisida $\left(a_{1} b_{1}\right)$. Aplikasi fungisida dilakukan sebanyak tiga kali. Untuk perlakuan penyarungan buah, buah disarungi menggunakan kantong plastik transparan berukuran $11 \mathrm{~cm}$ x $23 \mathrm{~cm}$ kemudian plastik diikat pada tangkai buah menggunakan karet gelang, sedangkan kontrol hanya diberi label saja. Penyarungan buah dilakukan pada perlakuan penyarungan buah kakao $\left(a_{1} b_{0}\right)$ dan kombinasi penyarungan buah kakao dengan aplikasi fungisida $\left(a_{1} b_{1}\right)$.

Data hasil penelitian dianalisis secara statistik deskriptif menggunakan Microsoft Excel 2007. Pengamatan dilakukan setiap minggu dimulai satu minggu setelah aplikasi. Peubah yang diamati adalah jumlah buah yang terkena busuk buah, jumlah buah terserang PBK. Keterjadian serangan PBK (\%) dan keterjadian penyakit (\%) serta keparahan penyakit (\%) dihitung dengan rumus sebagai berikut. Keterjadian serangan PBK (\%) dihitung dengan rumus :

$$
I S=\frac{n}{N} \times 100 \%
$$

Keterangan:

IS = Intensitas serangan

$\mathrm{n}=$ Jumlah buah terinflasi

$\mathrm{N}=$ Jumlah buah yang diamati

Keterjadian penyakit (\%) dihitung dengan rumus :

$$
K T=\frac{n}{N} \times 100 \%
$$

Keterangan:

$\mathrm{KT}=$ Keterjadian penyakit

$\mathrm{n}=$ Jumlah buah terinfeksi

$\mathrm{N}=$ Jumlah buah yang diamati

Keparahan penyakit (\%) dihitung dengan rumus :

$$
K P=\frac{\sum(n \times v)}{N \times Z} \times 100 \%
$$

\section{Keterangan:}

$\mathrm{KP}=$ Keparahan penyakit

$\mathrm{n}=$ Jumlah buah terinfeksi dalam setiap kategori

$\mathrm{v}=$ Kategori (skor) infeksi

$\mathrm{N}=$ Jumlah buah yang diamati

$\mathrm{Z}$ = Kategori (skor) tertinggi yang digunakan (5)

\section{HASIL DAN PEMBAHASAN}

Hasil penelitian menunjukkan bahwa penyarungan buah mampu menurunkan serangan hama penggerek buah kakao. Buah yang tidak disarungi pada umumnya terjadi perubahan warna pada kulit buah yaitu tampak hijau berbelang merah atau jingga, sedangkan pada buah yang disarungi tidak terjadi perubahan warna (Gambar 
1a). Apabila dibelah, buah yang tidak disarungi bijibijinya saling melekat dan berwarna kehitaman, biji tidak berkembang dan ukurannya menjadi lebih kecil. Sedangkan buah yang disarungi dengan plastik terlihat matang sempurna dan biji-biji tidak saling melekat (Gambar 1b).

Adanya perubahan warna hijau berbelang merah atau jingga serta biji-biji yang saling melekat berwarna kehitaman merupakan indikasi adanya serangan hama penggerek buah kakao (Wardojo, 1994 dalam Depparaba, 2002). Penyarungan buah terlihat mampu mengendalikan hama penggerek buah kakao. Intensitas serangan hama penggerek buah yang tidak disarungi dengan plastik sebesar $90 \%\left(\mathrm{~A}_{0} \mathrm{~B}_{1}\right)$, setelah buah disarungi buah terserang penggerek buah menjadi $5 \%$ $\left(\mathrm{A}_{1} \mathrm{~B}_{1}\right)$ (Gambar 2a). Pada penelitian ini gejala awal penyakit busuk buah kakao terlihat pada pengamatan minggu ke-2 (14 hari setelah aplikasi). Gejala terlihat pada perlakuan penyarungan buah dan kontrol berupa bercak-bercak hitam pada permukaan buah dan kemudian meluas ke semua bagian permukaan buah (Gambar 1c). Hasil penelitian menunjukkan bahwa perlakuan fungisida berbahan aktif asam fosfit terlihat mampu menurunkan keterjadian penyakit busuk buah kakao. Penyakit busuk buah yang tidak dilakukan aplikasi fungisida yaitu $30 \%$ menjadi $8 \%$ pada buah yang diaplikasikan fungisida. Aplikasi fungisida berbahan aktif asam fosfit terlihat mampu mengendalikan penyakit busuk buah kakao jika buah tidak disarungi plastik, namun penyakit busuk buah kakao menjadi meningkat jika buah diaplikasikan fungisida berbahan aktif asam fosfit yang dikombinasikan dengan penyarungan buah. Penyarungan buah kakao yang tidak disertai dengan aplikasi asam fosfit menyebabkan serangan busuk buah menjadi meningkat dibandingkan kombinasi penyarungan buah dan aplikasi asam fosfit, sedangkan buah yang tidak disarungi dan tidak diaplikasikan asam fosfit (kontrol) maka potensi terserang patogen lebih tinggi daripada buah-buah dengan perlakuan lainnya (Gambar 2b).
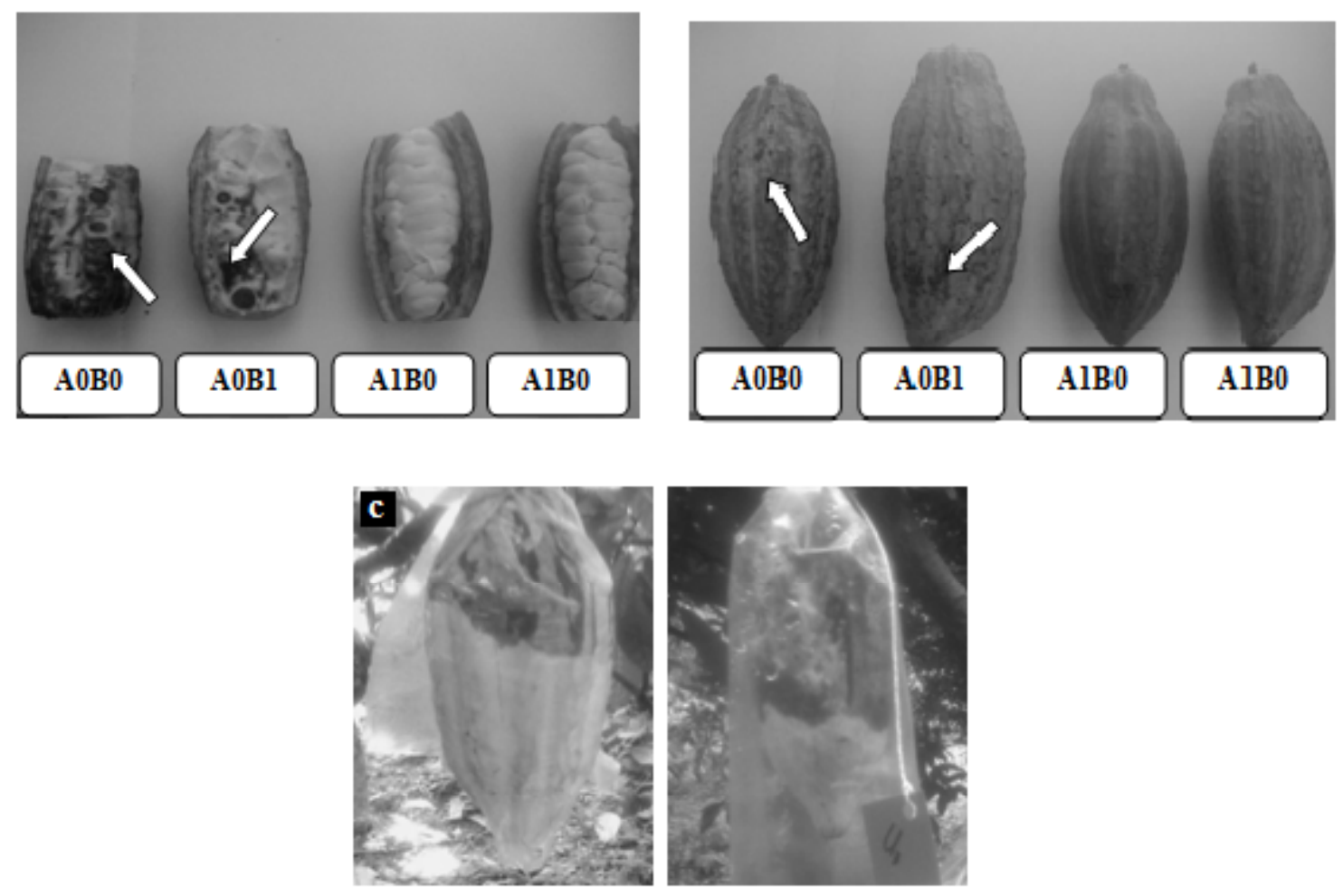

Gambar 1. (a) Gejala serangan hama penggerek buah kakao berupa perubahan warna hijau berbelang merah atau jingga (tanda panah). (b) Gejala serangan hama penggerek buah kakao berupa biji - biji yang saling melekat berwarna kehitaman (tanda panah). (c) Gejala penyakit busuk buah kakao pada buah kakao yang disarungi dengan plastik (tanda panah). A0B0 $=$ kontrol, $\mathrm{A} 0 \mathrm{~B} 1=$ aplikasi asam fosfit tanpa penyarungan, $\mathrm{A} 1 \mathrm{~B} 0=$ penyarungan buah tanpa aplikasi asam fosfit, $\mathrm{A} 1 \mathrm{~B} 1=$ kombinasi penyarungan buah dan aplikasi asam fosfit. 

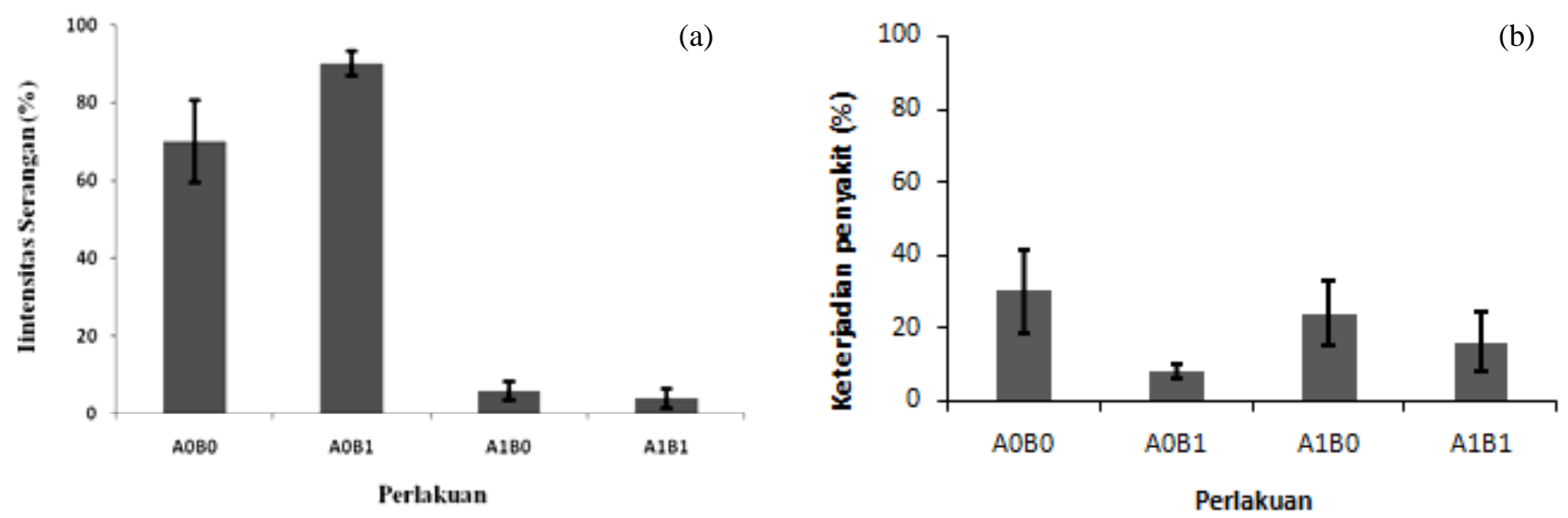

Gambar 2. (a) Diagram batang keterjadian serangan hama penggrek buah kakao berbagai perlakuan. (b) Diagram batang keterjadian busuk buah kakao berbagai perlakuan. A0B0 = kontrol, A0B1 = aplikasi asam fosfit tanpa penyarungan, $\mathrm{A} 1 \mathrm{~B} 0=$ penyarungan buah tanpa aplikasi asam fosfit, A1B1 = kombinasi penyarungan buah dan aplikasi asam fosfit, Bar $=$ standar error.

Hasil penelitian menunjukkan keparahan penyakit busuk buah meningkat pada setiap minggu pengamatan. Perkembangan keparahan penyakit busuk buah kakao pada akhir pengamatan (minggu ke 9) lebih rendah pada tanaman yang diberi perlakuan fungisida berbahan aktif asam fosfit, penyarungan buah serta kombinasi keduanya dibandingkan dengan keparahan penyakit tanaman kontrol (Gambar 3).

Berdasarkan hasil penelitian terlihat bahwa penyarungan buah kakao dengan plastik yang dikombinasi atau tidak dikombinasi asam fosfit dapat menekan serangan hama penggerek buah kakao. Menurut Sembel et al. (2011), penyarungan buah dapat melindungi buah secara fisik dari imago penggerek buah kakao untuk meletakan telur pada permukaan buah. Metode penyarungan buah dengan plastik, merupakan metode yang mencegah imago PBK meletakkan telur pada buah kakao. Menurut Morsamdono dan Wardojo (1984 dalam Mustafa, 2005) hampir 100\% buah yang disarungi bebas dari serangan PBK.

Pada penelitian ini buah yang disarungi menggunakan plastik masih terserang penggerek buah. Buah masih terserang penggerek buah karena plastik yang digunakan untuk menyarungi buah adalah plastik berukuran $11 \mathrm{~cm}$ x $23 \mathrm{~cm}$. Plastik ini berukuran kecil sehingga ketika buah mulai membesar akan menyebabkan ujung buah tidak tertutupi sehingga buah masih dapat terserang hama penggerek. Oleh karena itu menutupi seluruh permukaan buah secara fisik akan sangat efektif melindungi buah dari serangan hama penggerek.
Penyarungan buah efektif melindungi buah dari hama penggerek buah, namun penyarungan buah menyebabkan buah yang terserang busuk buah menjadi meningkat (lebih tinggi) dibandingkan buah yang tidak disarungi (diaplikasikan fungisida) dan buah yang diberi perlakuan kobinasi penyarungan buah dan aplikasi fungisida. Hal ini disebabkan karena uap air tetap berada disekitar buah karena tertahan oleh plastik. Akibatnya disekitar buah menjadi lembab karena adanya uap air disekitar buah kakao. Menurut Kresnawaty et al. (2010) intensitas serangan busuk buah pada penyarungan buah lebih tinggi karena penyarungan buah mengakibatkan kelembaban permukaan buah bertahan tinggi dan dalam prosesnya terjadi pelukaan pada permukaan buah, sehingga buah menjadi mudah terinfeksi.

Pada perlakuan penyarungan buah yang dikombinasikan dengan asam fosfit, buah kakao masih terserang busuk buah karena keadaan buah yang lembab. Sedangkan buah yang hanya di aplikasikan asam fosfit tanpa penyarungan buah kondisi sekitar buah tidak terlalu lembab sehingga serangan patogen busuk buah lebih rendah dibandingkan buah yang dibungkus dan dikombinasikan dengan asam fosfit.

Selain faktor kelembaban, adanya semut atau vertebrata diduga dapat membawa jamur Phytophthora palmivora dan membantu menyebarkan jamur patogen. Secara tidak sengaja patogen Phytophthora terbawa oleh semut dan berpindah antar buah atau dari tanah ke buah. Menurut Rubiyo dan Amaria (2013) penyebaran penyakit $P$. palmivora dapat melalui air, semut, tikus, tupai, bekicot yang dijumpai di perkebunan kakao. 


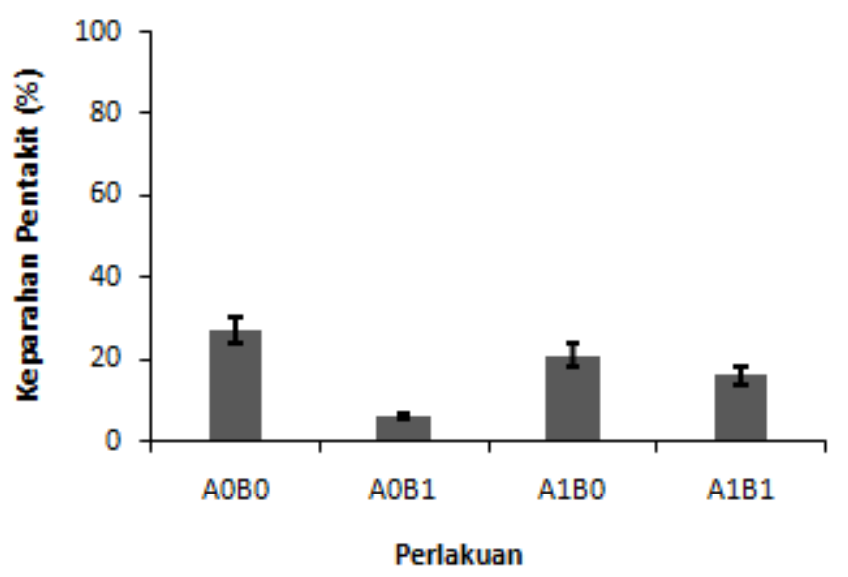

Gambar 3. Diagram batang keparahan busuk buah kakao berbagai perlakuan. A0B0 $=$ kontrol, A0B1 $=$ aplikasi asam fosfit tanpa penyarungan, $\mathrm{A} 1 \mathrm{~B} 0=$ penyarungan buah tanpa aplikasi asam fosfit, $\mathrm{A} 1 \mathrm{~B} 1=$ kombinasi penyarungan buah dan aplikasi asam fosfit, Bar = standar error.

Rosmana et al. (2010) melaporkan bahwa semut Iridomyrmex cordatus, Oecophylla smaragdina, Anoplolepis longipes, dan Crematogaster difformis memiliki kemampuan membawa $P$. palmivora yang merupakan penyebab penyakit busuk buah kakao. Semut dapat membawa jamur P. palmivora karena sering membuat sarang ditanah (McMahon \& Purwantara, 2004 dalam Rosmana et al. 2010). Peran semut ini sangat penting terutama dalam penyebaran secara vertikal seperti yang terjadi di Papua New Guinea dan Afrika (Konam \& Guest, 2004 dalam Rosmana et al., 2010).

\section{KESIMPULAN}

Dari penelitian ini dapat disimpulkan bahwa penyarungan buah terlihat dapat melindungi buah dari hama penggerek buah, namun penyarungan buah menyebabkan buah yang terserang busuk buah menjadi meningkat, dan asam fosfit terlihat mampu menekan pertumbuhan busuk buah kakaojika buah tidak dibungkus plastik, namun busuk buah kakao meningkat jika buah di bungkus plastik.

\section{DAFTAR PUSTAKA}

Balai Besar Pelatihan Pertanian. 2013 a. Hama PBK pada Kakao. http://bbppketindan.bppsdmp. deptan.go.id. Diakses tanggal : 4 Desember 2013.
Balai Besar Pelatihan Pertanian. 2013 b. Penyakit Busuk Buah (PBB) Kakao. http:// bbppketindan.bppsdmp.deptan.go.id. Diakses tanggal : 4 Desember 2013.

Departemen Pertanian. 2013. Peta Penyebaran OPT Utama Kakao. http://ditjenbun.deptan.go.id. Diakses tanggal : 3 Desember 2013.

Depparaba, F. 2002. Penggerek buah kakao (Conopomorpha cramerella Snellen) dan penanggulangannya. Jurnal Litbang Pertanian. 21 (2): 69-74.

Efri. 2010. Pengaruh ekstrak berbagai bagian tanaman mengkudu (Morinda citrifolia) terhadap perkembangan penyakit antraknosa pada tanaman cabe (Capsicum annuum L.). J.HPT Tropika. 10 (1): 52-58.

Kresnawaty, I., A. Budiani, A. Wahab, dan D. Taniwiryono. 2010. Aplikasi biokaolin untuk perlindungan buah kakao dari serangan PBK, Helopeltis spp. dan Phytophthora palmivora. Menara Perkebunan. 78 (1): 25-31.

Misnawi dan W. Teguh. 2008. Potential uses of cocoa bean infested by Conopomorpha cramerella for polyphenol extraction. ASEAN Food Journal. (1): 27-34 
Mustafa, B. 2005. Kajian Penyarungan Buah Muda Kakao Sebagai Suatu Metode Pengendalian Penggerek Buah Kakao (PBK) Conopomopha cramerella Snellen (Lepidoptera: Gracillariidae). Prosiding Seminar Ilmiah dan Pertemuan Tahunan PEI dan PFI XVI Komda Sulawesi Selatan. Makasar.

Radar Lampung. 2013. Produksi Anjlok, Petani Kakao Alih Profesi. http://www.radarlampung.co.id. Diakses pada tanggal : 4 September 2013.

Republika Online. 2009. Petani Kakao Di Lampung Keluhkan Hama. http://www.republika.co.id/ berita/breaking-news/nusantara. Diakses pada tanggal : 4 September 2013.

Roesmiyanto, S. Yuniastuti, dan M. Sugiyarto. 2000. Pengaruh cara aplikasi fungisida asam fosfit padapengendalian penyakit busuk pangkal dan akar phytophthora tanaman jeruk. http:/ lagris.fao.org/aos/records/ID2004001039. Diakses tanggal : 4 maret 2014.
Rosmana, A., C. Waniada, M. Junaid, dan A. Grassa. 2010. Peranan semut Iridomirmex cordatus (Hyminoptera: Formicidae) dalam menularkan patogen busuk buah Phytophthora palmivora. Pelita Perkebunan. 26 (3): 169-176.

Rubiyo dan Amaria, W. 2013. Ketahanan tanaman kakao terhadap penyakit busuk buah (Phytophthora palmivora Butl.). Perspektif. 12 (1): 23-36.

D.T. Sembel, J. Watung, M. Shepard, M. Hammig, G.R. Camer. 2011. Pengendalian penggerek buah kakao, Conopomorpha cramerella Snellen pada perkebunan kakao di Sulawesi Utara dengan menggunakan plastik polimer. Jurnal Pertanian. 17 (2): 102-108. 